\title{
From Fieldsite to 'Fieldsite': Ethnographic Methods in the time of Covid
}

\section{Thomas Chambers}

(Senior Lecturer in Social Anthropology, Oxford Brookes University, UK)

In a request to develop a contribution to Studies in Indian Politics, I was asked - in the context of COVID-19 - to consider how ethnographers can respond to this new transformation of the field? With a variety of restrictions being placed on movement, travel and physical interaction, many ethnographers, researchers and students are finding their fieldwork plans curtailed or even cancelled. For anthropologists, and others who utilise ethnographic methods, these restrictions pose particularly prominent limitations. Since its inception, ethnography has built its legitimacy on the value of data gathered through 'being there'. Indeed, the process of undertaking long-term, embedded fieldwork is symbolically constructed as a 'rite of passage', a ritualised initiation into anthropology as a discipline (Gupta \& Ferguson, 1997). Yet, what is seen as constituting an authentic 'fieldsite' for ethnographic research has never been a fixed construct.

Within early anthropological traditions, the legitimacy of the 'fieldsite' was often predicated on its difference, its 'exoticism' and the degree to which it could be imagined as 'primitive'. Such evocations have, rightly, been criticised as contributing to processes of othering and as becoming entangled in colonial cosmologies of naturalised world orders and racial hierarchies. These issues have also been a field of contestation amongst Indian anthropologists and social scientists with postcolonial legacies and/or other hegemonic hierarchical assumptions feeding through into ongoing classificatory projects which continue to mark out certain communities as 'backward' or 'primitive' and entrench forms of governmentality (Sundar et al. 2000; Dirks, 2001; Basu \& De Jong, 2016). Yet, there is also a long history of connection between activism, advocacy and anthropological fieldwork. In its earliest forms, 
this has included, among many other interventions, Sarat Chandra Roy's (1912; 1915) efforts with regard to the legal recognition of Oraon and Munda communities in India and the anti-racist collaborations of W.E.B. Dubois and Frantz Boas in the US at the start of the $20^{\text {th }}$ century. Whilst a substantial history of academic discourse and debate lies between these earlier activities and the contemporary moment, in the context of this article the long history of advocacy and activism in anthropology acts to remind us that 'fieldsites' are not disassociated spaces of abstract study but are deeply entangled in historical/contemporary connections and in (often very personal) relationships between ethnographers and 'the field'.

But what is a 'fieldsite'? Whilst much of early anthropology tended towards idealisations which associated the legitimacy of a fieldsite with its relative remoteness, from the 1920s Chicago-based Sociologists took anthropology's primary method - ethnography - and applied it to poor inner city urban neighbourhoods in the US. Whilst many of the problematics of exoticisation - in this case of working class or immigrant communities - were carried over, the body of research that emerged illustrated the value of ethnographic research in contexts beyond those which dominated anthropology at the time. From the late 1950s, anthropologists influenced by Marxist strands of social theory also began attending to urban spaces, factory floors and forms of proletarian resistance. The reflexive turn of the 1970s and 80s shifted the lens from 'the fieldsite' onto the anthropologist and questioned the objective authenticity of fieldwork itself (e.g. Ruby, 1982). The later emergence of multi-cited ethnography likewise challenged conceptions of 'the fieldsite' as a singular, static location (e.g. Marcus, 1995). More recently, netnography and autoethnography have pushed further at the boundaries of how a 'fieldsite' might be imagined by engaging with online or virtual spaces or by treating the bodies and subjectivities of ethnographers themselves as a 'fieldsite' (see: Hine, 2017).

In a recent article, Yarimar Bonilla \& Jonathan Rosa (2005) describe online research around the Black Lives Matter (BLM) movement. In this context, they focus on the social media hashtag (\#) as a potential 'fieldsite'. Picking up the narrative from the shooting of a young black man, Michael Brown 
$\mathrm{Jr}$, in 2014 by police in Ferguson, Missouri (United States), they trace the rapid emergence and effects of the '\#Ferguson' tag in social media posts. Here, they detail how \#Ferguson became intertextualised with other hashtags (e.g. \#Standingrock, \#Palestine, \#BlackLivesMatter, \#DalitLivesMatter) and connected to forms of activism and protest in material contexts both within the US and elsewhere. In so doing, Bonilla \& Rosa challenge conceptions of hashtag activism as not being 'real' activism and instead illuminate the intermingling and fluidity of material and virtual spaces. They suggest that social media offers a forum for those marginalised within formal political spaces to develop agendas and ferment social transformation. For Bonilla \& Rosa, then, the hashtag is very much a 'fieldsite', one which offers its own complexities, connections and engagements. Importantly, it also represents a site that is open to participation and/or observation, thus allowing the ethnographer to engage in research that embodies many of the principles of 'being there'.

Paloma Gay Y Blasco (2012) also offers a thickly descriptive piece of netnographic research in the context of transnational adoptions between China and the USA. Here, she traces adoption processes through a 'fieldsite' consisting of online worlds - blogs, YouTube videos and other media - that USbased adopting families create. The blogs and videos told the story of each family as they moved towards, what the prospective parents referred to as, 'Gotcha Day'. Blasco sees these online spaces as being highly significant in two ways. Firstly, they were sites of kinning and relatedness-making, as the 'expectant' parents wrote poems and prayers to the child they had not yet met. Here, relatedness could be constructed in the absence of anything shared (e.g. substance, time, etc.) through online performances. Relatedness was also evoked via consumption practices (clothes, cribs, toys etc.), which, Blasco argues, are a central marker of the American cultural context. Secondly, Blasco identifies these online activities as constituting forms of self-making within which an average, white, middle-class, Christian, American family is transformed into something exceptional. Here, the prospective parents became not only adopters but also saviours and heroes who were re-cast as engaging in God-given work. However, Blasco also indicates how these online performances were cross-cut by uneven relations of power and intermingled with material contexts. Relatedness was 
created in the absence of shared substance but was also fashioned within a narrative where the child adoptee was rendered agentless, with the very evocation of 'Gotcha Day' suggesting a form of possession. Thus, the child became orientalised as the romanticized other and the positioning of the adopter as 'saviour' interplayed with underlying assumptions of American cultural superiority.

Bonilla \& Rosa and Blasco offer us ethnographic material that pushes at the boundary of what we might imagine to constitute a 'fieldsite'. They also use methods that can be deployed in degrees of Covid lockdown (although this may be constrained by internet access). As with any 'fieldsite', however, there are limitations, ethical considerations and ambivalences. Additionally, other methods - such as autoethnography or 'anthropology at home' (in the strictest sense of the term) - could also offer avenues for ethnographic research in lockdown conditions. I want to conclude, however, by suggesting that we remain vigilant to our own privilege during a time when those suffering the worst ravages of Covid are also the same groups who experienced the most deeply felt forms of marginalisation and exploitation in the pre-Covid context. My own research (e.g. Chambers, 2020a; Chambers 2020b) is focused on craftworkers and migrants from Muslim neighbourhoods in the north of India and in the Gulf. Already highly marginalised by their religious and class status, not only has Covid brought even greater uncertainty to precarious livelihoods but evocations of 'Covid Jihad' and additional forms of othering/scapegoating by actors within the Indian state and factions of the media has further deepened a sense of marginalisation.

Whilst my own plans for further fieldwork are also constrained, the presence of communication technologies such as WhatsApp and Facebook has allowed me to remain engaged with friends and others from my prior fieldwork. This has proven critical in allowing me to follow events as they unfold (albeit from a distance) but also acts to further blur the boundaries of where the 'fieldsite' might be conceived as beginning and ending. For those undertaking research for the first time, a lack of access to physical 'fieldsites' might limit the degree to which these tools can be used. However, many 'groups' and 'chats' on social media are open or can be entered with the permission of an admin and 
hence offer those who have not established prior relationships on a face to face basis a way to begin building connections with potential informants who may later, either within the online space or through physical contact as lockdown restrictions change, become gatekeepers, key informants and (importantly for ethnographic research) friends.

\section{References}

Basu, P., \& De Jong, F. (2016). Utopian archives, decolonial affordances Introduction to special issue. Social Anthropology, 24(1), 5-19.

Blasco, P. G. Y. (2012). 'A wondrous adventure': mutuality and individuality in Internet adoption narratives. Journal of the Royal Anthropological Institute, 18(2), 330-348.

Bonilla, Y., \& Rosa, J. (2015). \# Ferguson: Digital protest, hashtag ethnography, and the racial politics of social media in the United States. American ethnologist, 42(1), 4-17.

Chambers, T. (2020). 'Lean on me': Sifarish, mediation \& the digitisation of state bureaucracies in India. Ethnography, 1466138120940755.

Chambers, T. (2020). Networks, Labour and Migration among Indian Muslims Artisans. London: UCL Press.

Dirks, N. B. (2001). Castes of mind: Colonialism and the making of modern India. New Jersey: Princeton University Press.

Gupta, A., \& Ferguson, J. (1997). Discipline and practice: 'The field' as site, method, and location in anthropology. In Gupta, A., Ferguson, J., \& Ferguson, J. G. (Eds.). (1997). Anthropological locations: Boundaries and grounds of a field science. California: University of California Press. 1-47

Hine, C. (2017). 'Ethnographies of online communities and social media: Modes, varieties, affordances'. The SAGE handbook of online research methods. In Fielding, Nigel G., Raymond M. Lee, and Grant Blank, (eds). The SAGE handbook of online research methods. London: Sage. 401-415.

Marcus, G. E. (1995). Ethnography in/of the world system: The emergence of multi-sited ethnography. Annual review of anthropology, 24(1), 95-117.

Roy, S. C. (1912). The Mundas and their country. Bombay: Asia Publishing House.

Roy, S. C. (1915). The Oraons of Chota Nagpur. Calcutta: Brahmo Mission Press

Ruby, J. (Ed.). (1982). A crack in the mirror: Reflexive perspectives in anthropology. Philadelphia: University of Pennsylvania Press.

Sundar, N., Deshpande, S., \& Uberoi, P. (2000). Indian anthropology and sociology: Towards a history. Economic and political weekly, 35(24), 1998-2002. 